\title{
Trichoderma harzianum genes induced during growth on Rhizoctonia solani cell walls
}

\author{
Valérie Vasseur,† Marc Van Montagu and Gustavo H. Goldman $\ddagger$ \\ Author for correspondence: Marc Van Montagu. Tel: +329 2645170. Fax: +3292645349. \\ e-mail: BITNET mamon@gengenp.rug.ac.be
}

Laboratorium voor Genetica, Universiteit Gent, K. L. Ledeganckstraat 35, B-9000 Gent, Belgium

\begin{abstract}
Trichoderma harzianum is a biocontrol agent that attacks a range of economically important phytopathogenic fungi. In an attempt to identify genes specifically expressed by $T$. harzianum during growth on cell walls of Rhizoctonia solani, we carried out differential screening of an induced CDNA library. In this paper we report the analysis of the sequence and expression of two CDNA clones that encode putative mycoparasitism-related proteins of $T$. harzianum. One of these clones corresponds to a gene, inda1, that encodes a protein of 570 amino acids with a predicted molecular mass of $62853 \mathrm{Da}$. The predicted amino acid sequence of inda1 showed a high degree of similarity with amino acid permeases from several other organisms. The other CDNA clone corresponds to a gene, indc11, that encodes a novel protein of 340 amino acids with a predicted molecular mass of $37010 \mathrm{Da}$. The use of this methodology should provide specific genetic markers to follow mycoparasitism by Trichoderma spp.
\end{abstract}

Keywords: Trichoderma barzianum, Rbizoctonia solani cell walls, mycoparasitism

\section{INTRODUCTION}

Modern agriculture is very strongly dependent on fungicides. The repeated use of these pesticides has not only polluted the environment, but many pesticides have also become useless owing to the development of resistance among the target organisms. One possible alternative to synthetic fungicides is the use of biological control agents. Many natural biocontrol agents have been shown to be effective in controlling plant pathogens (see reviews by Chet, 1990; Manocha, 1991). However, biocontrol is not often used in commercial agricultural production because control of plant diseases with microbial agents has been less effective and reliable than with synthetic fungicides. The improvement of biocontrol efficacy requires a better knowledge of the mechanisms involved in the control of plant pathogens.

The fungus Trichoderma barzianum has been used as a biocontrol agent and shown to attack a range of econ-

\footnotetext{
†Present address: ESMISAB-Laboratoire de Microbiologie et Biochimie, Technopole Brest-Iroise, F-29280, Plouzané, France.

¥Present address: Universidade de Săo Paulo, Faculdade de Ciéncias Farmacêuticas de Ribeirăo Preto, Via do Café S/N, 14040-903, Ribeirăo Preto, SP, Brazil.

The EMBL accession numbers for the inda1 and indc11 nucleotide sequences reported in this paper are Z22594 and Z22221, respectively.
}

omically important aerial and soil-borne fungal plant pathogens. In soil, T. barzianum strains have been used as antagonists against several plant-pathogenic fungi, for example Rbizoctonia solani, Botrytis cinerea and Sclerotium rolfsii (Chet, 1987). A great deal of information about the factors involved in the antagonistic properties of $T$. barzianum has been identified. These include volatile and non-volatile antibiotics, and hydrolytic enzymes such as chitinases, glucanases and proteases (Dennis \& Webster, 1971a, b; Elad et al., 1982; Ridout et al., 1986, 1988; Claydon et al., 1991; Geremia et al., 1991; Graeme-Cook \& Faull, 1991; Ulhoa \& Peberdy, 1991; Avent et al., 1992; De La Cruz et al., 1992; Di Pietro et al., 1993; Harman et al., 1993; Lorito et al., 1993). Recently, two mycoparasitism-related genes from $T$. harzianum, encoding an alkaline proteinase (Geremia et al., 1993) and an endochitinase (Hayes et al., 1994), have been isolated and characterized.

When mycoparasitic strains of Trichoderma spp. grow on host cell walls, induction and/or derepression of genes involved in mycoparasitism has been found to occur. In addition, glucose represses the activity and/or expression of hydrolytic enzymes important for the degradation of the cell walls (Geremia et al., 1991, 1993). Our approach to identify factors determining mycoparasitic abilities of $T$. barzianum was to isolate genes of this species that show induced or increased expression during growth on $R$. 
solani cell walls. Identification of the proteins encoded by these genes might help elucidate some of the molecular and cellular events involved in mycoparasite-host interactions.

To isolate the putative mycoparasitism genes, we carried out differential screening of an induced cDNA library. In this paper we report the analysis of the sequence and expression of two cDNA clones from this library. One corresponds to a gene encoding a putative amino acid permease (inda1), and the other corresponds to a gene encoding a novel polypeptide (indc11).

\section{METHODS}

Fungal strains and growth media. T. harzianum (IMI 206040) was grown in Erlenmeyer flasks containing $50 \mathrm{ml}$ minimal medium (MM: $0.2 \%$ asparagine, $0.2 \% \quad \mathrm{NaNO}_{3} \quad 0.05 \%$ $\mathrm{MgSO}_{4} .7 \mathrm{H}_{2} \mathrm{O}, 0.05 \% \mathrm{KCl}, 0.1 \% \mathrm{KH}_{2} \mathrm{PO}_{4}, \mathrm{pH} 6.0$ ) supplemented with $2 \%(\mathrm{w} / \mathrm{v})$ glucose on a rotatory shaker (150 r.p.m.) at $28{ }^{\circ} \mathrm{C}$ for $3 \mathrm{~d}$. The mycelium was then harvested, rinsed with sterile water and transferred to Erlenmeyer flasks with the same medium containing either $2 \%$ glucose or $0 \cdot 1 \%$ cell walls of $R$. solani (prepared as described by Goldman et al., 1992a). Mycelium was harvested after 24, 48 and $72 \mathrm{~h}$, lyophilized, and stored at $-20^{\circ} \mathrm{C}$.

cDNA library. The cDNA library was constructed using poly $(\mathrm{A})^{+}-\mathrm{RNA}$ obtained from $T$. barzianum grown for $24 \mathrm{~h}$ in MM containing cell walls of $R$. solani $\left(1 \mathrm{mg} \mathrm{m}^{-1}\right)$ as sole carbon source (Goldman et al., 1992b). Total RNA and poly(A) ${ }^{+}-\mathrm{RNA}$ were isolated from fungal mycelia according to a previously described protocol (Jones $e t$ al., 1985), adapted for the largescale isolation of RNA and using a poly-A tract mRNA isolation kit (Promega).

Differential screening. This was carried out essentially as described by Gasser et al. (1989) and M. H. de S. Goldman et al. (1992). Bacterial colonies (3000) were stored in microtitre plates containing Luria-Bertani (LB) medium supplemented with ampicillin. Duplicate nylon replica filters (Hybond-N, Amersham) were used on each of the plates and treated as recommended by the manufacturer. Radioactive plus/minus cDNA probes were synthesized from poly $(\mathrm{A})^{+}-\mathrm{RNA}$ of mycelium grown on glucose ('minus') or cell wall ('plus') medium. Hybridization probes were synthesized from $1 \mu \mathrm{g}$ of poly $(\mathrm{A})^{+}$ RNA in a reaction similar to the first-strand cDNA synthesis. Modifications introduced were the use of $100 \mu \mathrm{Ci}(3.7 \mathrm{MBq})$ $\left.{ }^{32} \mathrm{P}\right] \mathrm{dCTP}$ for the first hour of reaction and the use of random hexanucleotides as primers. Unlabelled dCTP was then added to a final concentration of $0.5 \mathrm{mM}$ and the reaction was continued for $30 \mathrm{~min}$. The labelled cDNA/RNA hybrids were purified on Nensorb columns (Nensorb). In preparation for hybridization, the probes were denatured and the RNA was hydrolysed by adding $60 \mu \mathrm{l} 1.0 \mathrm{M} \mathrm{NaOH}$, followed by $30 \mathrm{~min}$ incubation at room temperature. The base was neutralized by adding $60 \mu \mathrm{l}$ $1.0 \mathrm{M} \mathrm{HCl}$ and $60 \mu \mathrm{l} 20 \times \mathrm{SSPE}(1 \times \mathrm{SSPE}: 0 \cdot 15 \mathrm{M} \mathrm{NaCl}$, $10 \mathrm{mM}$ sodium phosphate, $1 \mathrm{mM}$ EDTA, $\mathrm{pH} 7 \cdot 4)$. Filters were prehybridized in a solution containing $6 \times$ SSC $(1 \times$ SSC: $0 \cdot 15 \mathrm{M} \mathrm{NaCl}, 0 \cdot 015 \mathrm{M}$ sodium citrate, $\mathrm{pH} 7 \cdot 0$ ), $1 \%$ (w/v) SDS, $100 \mu \mathrm{g}$ denatured carrier DNA ml ${ }^{-1}, 0 \cdot 25 \%$ milk powder for $1 \mathrm{~h}$ at $68^{\circ} \mathrm{C}$. The labelled cDNA was added to the prehybridization solution to a final concentration of $10^{6}$ c.p.m. $\mathrm{ml}^{-1}$ and incubated at $68{ }^{\circ} \mathrm{C}$ for $36-48 \mathrm{~h}$. The probe-specific activities were adjusted to equality and equivalent amounts of radioactivity per $\mathrm{ml}$ of hybridization solution were used. Filters were washed sequen- tially at $68{ }^{\circ} \mathrm{C}$ in $6 \times \mathrm{SSC}, 0.1 \% \mathrm{SDS}$ for $30 \mathrm{~min}$, and in $2 \times$ SSC, $0.1 \%$ SDS for 30 min. Filters were exposed to Kodak-X Omat films overnight between intensifying screens at $-70^{\circ} \mathrm{C}$.

DNA/RNA manipulations. Restriction enzyme digests and DNA ligation were performed according to the recommendations of the suppliers (Boehringer and Amersham). Plasmid DNA isolation and Southern blotting were all performed using standard procedures (Sambrook et al., 1989). DNA probes were made using a primer system according to the manufacturer (Boehringer). The complete sequence of the inda1 and indc11 genes was determined by the dideoxy-chain termination method (Sanger et al., 1977) from both strands using synthetic oligonucleotide primers.

For Northern analysis, T. barzianum was grown by inoculating MM supplemented with $2 \%(\mathrm{w} / \mathrm{v})$ glucose with $3 \times 10^{4}$ conidiospores per $\mathrm{ml}$ medium. The cultures were incubated in a reciprocal shaker at $28^{\circ} \mathrm{C}$ for $3 \mathrm{~d}$, harvested by filtration through a Whatman filter (no. 1), and washed thoroughly with TES buffer $(50 \mathrm{mM}$ Tris, $50 \mathrm{mM} \mathrm{NaCl}, 5 \mathrm{mM}$ EDTA, pH 8.0). Equal amounts of mycelium were transferred to $\mathrm{MM}$ supplemented with $2 \%$ glucose or cell walls $\left(1 \mathrm{mg} \mathrm{ml}^{-1}\right)$ of the phytopathogenic fungus $R$. solani. This last condition was defined throughout this work as cell-wall-grown, i.e. growth in liquid medium having a cell wall preparation of $R$. solani as sole carbon source (Goldman et al., 1992a). Mycelium was collected, disrupted and total RNA extracted. In all Northern analysis experiments, RNA concentration was normalized by hybridization with a $\beta$-tubulin gene from Trichoderma viride (tub1; Goldman et al., 1993).

\section{RESULTS}

\section{Isolation of specific $T$. harzianum cDNA clones grown on cell walls}

We isolated specific cDNA clones from a $T$. barzianum cell-wall-grown cDNA library by differential screening against probes from $T$. barzianum grown on glucose or on cell walls of R. solani, as described by Gasser et al. (1989) and M. H. de S. Goldman et al. (1992). The initial screening resulted in the identification of 65 clones (from 3000 clones of a non-amplified library) and a secondary screening in $15 \mathrm{cDNA}$ clones that hybridized only to cDNA probes derived from T. barzianum grown on cell walls. For further analysis, we decided to choose only the clones which in Northern analysis experiments hybridized with mRNAs isolated from cell-wall-grown $T$. harzianum (see below). These preliminary experiments showed that only eight clones hybridized to mRNA obtained from $T$. barzianum grown on cell walls. Southern analysis experiments indicated that three of these clones crosshybridized at high stringency (data not shown). Thus, we obtained at the end of our screening six different clones which are expressed specifically during growth on cell walls of R. solani. Two of these CDNA clones, INDA1 and INDC11, were chosen for further analysis.

\section{inda1 and indc11 genes are expressed during growth of $T$. harzianum on cell walls}

To clarify the conditions under which the inda 1 and indc 11 genes were expressed, RNA was isolated from T. barzi- 


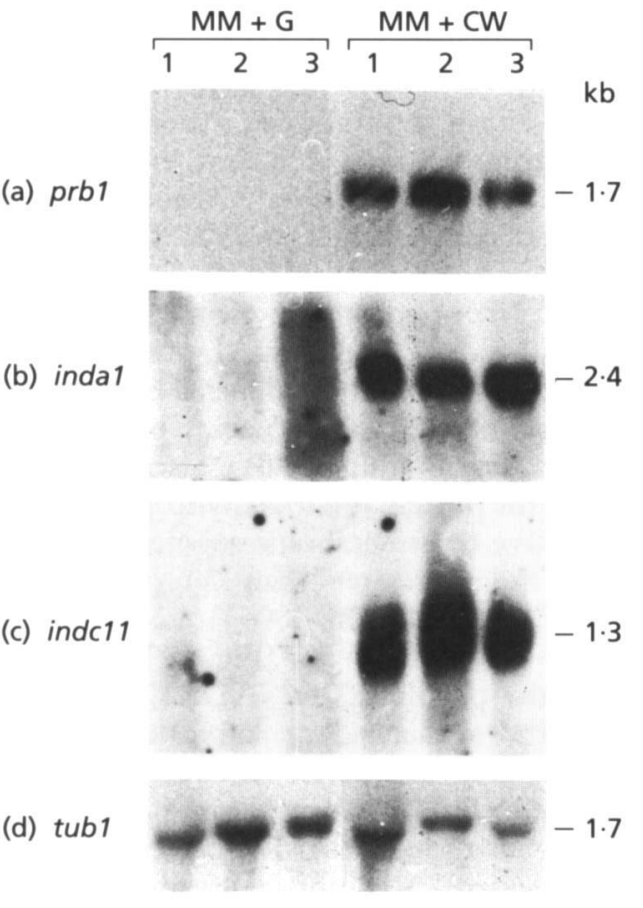

Fig. 1. Northern blot of mRNA obtained from $T$. harzianum grown on $\mathrm{MM}$ plus glucose $(\mathrm{MM}+\mathrm{G})$ or $R$. solani cell walls (MM + CW). Transcript levels of prb1 (a), inda1 (b), indc11 (c) and tub1 (d) in mycelia harvested 24 (lane 1), 48 (lane 2) and 72 (lane 3) $\mathrm{h}$ after transfer into $\mathrm{MM}+\mathrm{G}$ or $\mathrm{MM}+\mathrm{CW}$.

anum grown on cell walls and Northern analyses were carried out (Fig. 1). One gene expressed during mycoparasitism by $T$. harzianum is the prb1 gene, which encodes an alkaline proteinase (Geremia et al., 1993). Its expression was repressed in the presence of glucose and increased during cell-wall-grown T. harzianum (Fig. 1a). The inda1 gene specifies a single transcript of about $2.4 \mathrm{~kb}$ whereas the indc 11 gene specifies a single transcript of about $1.3 \mathrm{~kb}$ (Figs $1 \mathrm{~b}$ and 1c). $\beta$-Tubulin mRNA expression was constant during growth on glucose and cell walls (Fig. 1d). Both genes hybridized only with mRNA obtained from $T$. barzianum grown on cell walls. They did not hybridize with mRNA isolated during growth of $T$. barzianum in the presence of glucose. These data indicated that inda 1 and indc11 genes are specifically expressed in cell-wall-grown $T$. barzianum and repressed during growth on glucose.

\section{The INDA1 CDNA clone corresponds to a gene that encodes a putative amino acid permease}

The INDA1 cDNA clone contained an insert of $2 \cdot 1 \mathrm{~kb}$. The complete sequence of the inda1 gene of $T$. barzianum is shown in Fig. 2. The cDNA has an ORF of 1710 nucleotides. To determine whether inda 1 is a member of a gene family, we performed DNA blot hybridizations with genomic DNA prepared from $T$. harzianum (Fig. 3a). After digestion of the genomic DNA with appropriate
1 ggccaucaca agangagcan caccuaggec ttcatc atg tcg ma gag gag agt gGC CAT 61 GTC ACT CCC GAG MAG GGC GAC MAT GTC GTC GAC TAT CAG GCC AGC ACG ACA GTC $V$
115 CTC CCC AGC GAG GGC CCT GAS CGC GAC GCC MAC TGG TTC ACG CGC M 115 CTC CCC AGC GAG GGC 172 AAC GTC GAC TCC ITC AMG MAG MAG CAC TAT GGC CCG GGC ATG GTC GAG CIT GAG 222 CGT CCC ATG MG GCT CGC CAT CTT CAC ATG ATT GCC ATT GGT GGT TCC AIT GGT 276 GCT GGT TTC TTC GTC GGC ICG GGC GGT GCT CTO GCC MM GGT GGC CCT GGT TCT 330 CTC ITI GTC GAC TTC CTC ATT ATC GGT ATC ATG ATG TIC MAC GTC GTG TAC GCT 385 CTC G V

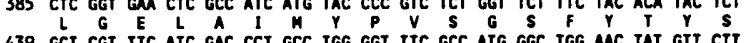
493 CAG TGG GCT GCC GT CII CCG CIT GA TIG ACA GIT TGT GGT AIT ACE ATA TCG 547 TAC TGG AAC TCG GAA ATC ACC ACA GCC GCT TGG ATC TCT CTC TTC CTC GGC GTC

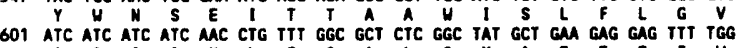
601 ATC ATC ATC ATC AAC CTG TTT GGC GCT CTC GGC TAT GCT GAA GAG GAG TIT TGG 655 GCA TCG TGC TrC AAO CIO GCT GCC ACC GTC ATC TTC ATC ATC ATC GCT ITT GTC $70 B$ CIT GTC CTC GGT GGT GGT CCC MAG GAT GGC CGA TAC CAC GAG TAC TGG GGT GCC

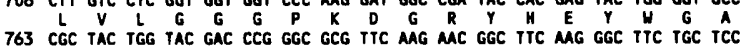

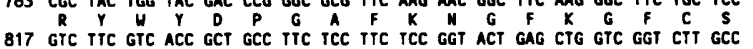
817 GTC TIC GTC ACC GCT GCC TTC TCC TIC TCC GGT ACT GAG CTG GTC GGT CTT GCC 871 GCT GCC GAG TCT ACT AAC CCC ACC AAG AAC ATG CCC GGT GCT ATC AMG CAG ATC 925 TTC TGG CGT ATC ACC ATC IIT TAC ATC CTC GGT CTC TTC TIT GTC GGC CTG CTG

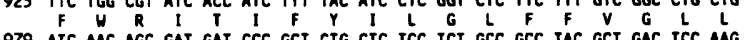
979 ATC MAC AGC GAT GAT CCC GCT CTG CTC TCC TCT GCC GCC TAC GCT GAC TCC MAG 1033 GCC TCT CCC TIT GTG CIT GTC GGC MAG TAC GCT GGC TTG MAG GGT ITC GAC CAC $A$
1087 TIC ATG MAC CTC GTC ATT CTC GCC TCC GTC ITO TCC ATC GGT GTC TCT GGT GTG

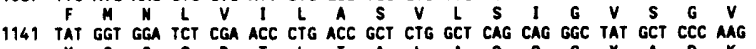
1141 TAT GGT GGA TCT CGA ACC CTG ACC GCT CTG GCT CAG CAG GGC $Y C_{Y} A_{P} A_{K}$

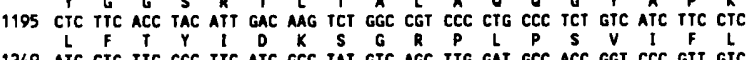
1249 ATC CTG TTC GGC TIC ATC GCC TAT GTC AGC ITG GAT GCC ACC GGT CCC GTT GTC

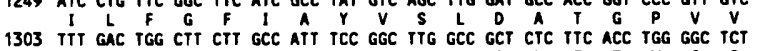

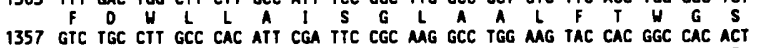
1357 GTC TGC CTT GCC CAC ATT CGA TTC CGC MG GCC TGG NAG TAC CAC GGC CAC ACT 1411 CTG GAT GAG ATT CCA TTC AAG GCT GCT GGC GGT GTC TAC GGC TCA TAC CTC GGC 1465 CIT TIC ATT TGC GTC AIT GTC CTE ATG GCT CAG TIC TAT ACC GCT ATT GCA GCC 1465 CIT TIC ATT TGC GTC ATT GTC CTG ATG GCT CAG TIC TAT ACC GCT AIT GCA GCC 1519 CCT CCC GGA TCA CCA GGC GTT GGT ACC GCA GAG GAC TTC TTC AMG CAG TAC CTG 1573 GCT GCT CCC GTC GIC CTC GGT TIC TGG ATC GIT GGA TGG CTG IGG AAG CGC CAG 1627 CCT TTC TTG AGA ACC AAG AAC AIT GAC GIT GAC ACT GGT CIC CGT GAG TIT GAC 1681 TGG GAC GAG RTC AAC GCA GAG I CGC DCA NGA D 1735 H D E I N A E R T R I A P L P A N R 566 1735 CGC ATC ATC CAC CAC ACC ITC TAA GAGCCCAAGC TCGACGATAM IITCTTTATC CATTTCTTTT 573 1799 TITTATTCA ACACATGTGT TGTTCCTICCG TCGATACAGT ATGGCATCAT GITGGATGCA GACTGGAGTT 1869 AATGAGGCGG AGTGAATTCG GATGACGATG ATGTAACGCT GTATATCCM CCACGCCTAC GATGCTGTGG 2009 GCCTCTAACG GGGATGGGA TCAAATCAAT ATATACCTG TCATACAACA MAMAMAMA AMAMAMAA

Fig. 2. Nucleotide sequence and predicted amino acid sequence of the $T$. harzianum inda1 gene (2.1 kb Sfil-Notl fragment).

restriction enzymes, few fragments could be identified in the restriction map of the clone hybridized to the INDA1 cDNA, indicating that inda1 is probably a single-copy gene. The inda $1 \mathrm{ORF}$ encodes a protein of 574 amino acid residues with a predicted molecular mass of $62853 \mathrm{Da}$ and a calculated $\mathrm{pI}$ of $7 \cdot 81$. The codon usage of the inda 1 gene resembles that of other Trichoderma genes (Vanhanen, 1991; Goldman et al., 1992a). Of the 61 codons, 9 are not used at all and 22 are used more than 10 times, coding for about $77 \%$ of the amino acid residues of INDA1(Table 1). Thus, no codon bias is apparent, a result in agreement with other genes expressed at low levels (Bennetzen \& Hall, 1982).

Comparison of the amino acid sequence of INDA1 with those of amino acid permeases from several other organisms revealed a striking identity (Fig. 4): 43.4\% with GAP1 from Saccharomyces cerevisae; $35.9 \%$ with HIP1 from S. cerevisae (Tanaka \& Fink, 1985); $34.1 \%$ with YCC5 from S. cerevisae (Tanaka \& Fink, 1985); 32.9\%

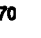

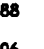
(an 象

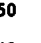

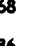

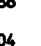

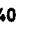

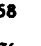
12

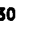

26 4. 82 (2)

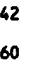
296 s. "s (2) ro , 48

6

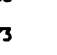
. 


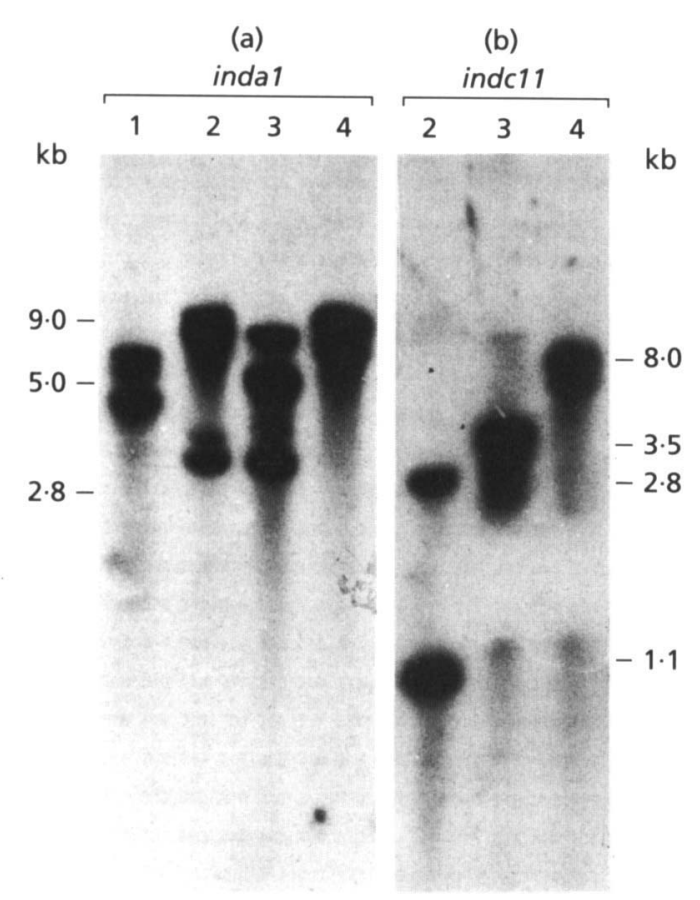

Fig. 3. Southern blot of T. harzianum genomic DNA. DNA was prepared according to Garber \& Yoder (1983) and digested with restriction endonucleases PstI (lane 1), HindlII (lane 2), EcoRI (lane 3) or BamHI (lane 4). Blots were probed with a ${ }^{32 \mathrm{p}-}$ labelled $2 \cdot 1 \mathrm{~kb}$ fragment from an INDA1 CDNA clone (a) or a $1.2 \mathrm{~kb}$ fragment from an INDC11 CDNA clone (b).

with LYSP from Escherichia coli (Steffes et al., 1992); and $27 \cdot 2 \%$ with CAN1 from S. cerevisiae (Hoffmann, 1985).

The identity to the GAP1 protein from $S$. cerevisiae is the highest value of similarity yet reported for amino acid permeases.

Experiments on the topology of membrane proteins have shown that structures predicted from hydropathy profiles are consistent with experimental methods of determining the structure of permeases (Ahmad \& Bussey, 1986; Gött \& Boos, 1988; Sophianopoulou \& Scazzocchio, 1989). We analysed the hydropathy profile of the INDA1 polypeptide (Fig. 5). The INDA1 putative transporter lacks a hydrophobic $\mathrm{N}$-terminal signal peptide, the whole $\mathrm{N}$-terminal region of 75 amino acids being hydrophilic. The $\mathrm{C}$-terminus of 39 amino acids is also hydrophilic. The remainder of the protein is highly hydrophobic, having 10 distinct putative transmembrane segments of an average hydropathy index greater than 30 (residues 98-114, 151-167, 182-198, 212-228, 300-316, 352-368, 401-417, $421-437,477-493$ and 511-527; Fig. 5). We also examined the hydropathy profile of the INDA1 permease with a number of the sequenced prokaryotic and eukaryotic transport proteins mentioned above. The hydropathy profile of the INDA1 permease was similar to all of the permeases, even though the number of putative transmembrane segments was not identical in all cases (data not shown; Fig. 5). Thus, based on the sequence homology and hydropathy profile of the INDA1, we propose that the inda 1 gene encodes a putative amino acid permease.

\section{The INDC11 cDNA clone corresponds to a gene that encodes a novel polypeptide}

The INDC11 cDNA clone contains an insert of approximately $1 \cdot 2 \mathrm{~kb}$. The cDNA has an ORF of 1020 nucleotides

Table 1. Codon usage of the T. harzianum inda1 and indc11 genes

\begin{tabular}{|c|c|c|c|c|c|c|c|c|c|c|c|c|c|c|c|}
\hline \multirow{2}{*}{$\begin{array}{l}\text { Amino } \\
\text { acid }\end{array}$} & \multirow[t]{2}{*}{ Codon } & \multicolumn{2}{|c|}{ Occurrence* } & \multirow{2}{*}{$\begin{array}{c}\text { Amino } \\
\text { acid }\end{array}$} & \multirow[t]{2}{*}{ Codon } & \multicolumn{2}{|c|}{ Occurrence* } & \multirow{2}{*}{$\begin{array}{c}\text { Amino } \\
\text { acid }\end{array}$} & \multirow[t]{2}{*}{ Codon } & \multicolumn{2}{|c|}{ Occurrence* } & \multirow{2}{*}{$\begin{array}{c}\text { Amino } \\
\text { acid }\end{array}$} & \multirow[t]{2}{*}{ Codon } & \multicolumn{2}{|c|}{ Occurrence* } \\
\hline & & inda1 & indc11 & & & indal & indc11 & & & indal & indc11 & & & inda1 & indc11 \\
\hline \multirow[t]{2}{*}{ Phe } & TTT & 9 & 4 & Ser & TCT & 13 & 1 & Tyr & TAT & 8 & 1 & Cys & TGT & 1 & 0 \\
\hline & TTC & 36 & 11 & & TCC & 10 & 8 & & TAC & 17 & 14 & & TGC & 4 & 2 \\
\hline \multirow[t]{6}{*}{ Leu } & TTA & 0 & 0 & & TCA & 2 & 1 & Stop & TAA & 1 & 1 & Stop & TGA & 0 & 0 \\
\hline & TTG & 6 & 1 & & TCG & 5 & 2 & & TAG & 0 & 0 & $\operatorname{Trp}$ & TGG & 18 & 6 \\
\hline & CTT & 12 & 0 & Pro & $\mathrm{CCT}$ & 6 & 4 & His & CAT & 2 & 2 & Arg & $\mathrm{CGT}$ & 5 & 0 \\
\hline & CTC & 21 & 15 & & $\mathrm{CCC}$ & 16 & 15 & & CAC & 9 & 5 & & $\mathrm{CGC}$ & 8 & 9 \\
\hline & CTA & 0 & 1 & & $\mathrm{CCA}$ & 2 & 1 & $G \ln$ & CAA & 0 & 1 & & CGA & 3 & 0 \\
\hline & CTG & 16 & 9 & & CCG & 3 & 5 & & $\mathrm{CAG}$ & 8 & 7 & & CGG & 0 & 1 \\
\hline \multirow[t]{3}{*}{ Ile } & ATT & 15 & 1 & Thr & ACT & 5 & 2 & Asn & $\mathrm{AAT}$ & 2 & 2 & Ser & $\mathrm{AGT}$ & 1 & 0 \\
\hline & ATC & 26 & 17 & & ACC & 14 & 9 & & $\mathrm{AAC}$ & 13 & 10 & & AGC & 4 & 7 \\
\hline & ATA & 1 & 1 & & ACA & 5 & 1 & Lys & AAA & 2 & 3 & Arg & AGA & 3 & 1 \\
\hline Met & ATG & 12 & 9 & & ACG & 3 & 5 & & AAG & 22 & 17 & & $\mathrm{AGG}$ & 0 & 2 \\
\hline \multirow[t]{4}{*}{ Val } & GTT & 7 & 2 & Ala & GCT & 28 & 0 & Asp & GAT & 5 & 3 & Gly & GGT & 29 & 1 \\
\hline & GTC & 32 & 18 & & $\mathrm{GCC}$ & 26 & 2 & & GAC & 16 & 14 & & GGC & 30 & 21 \\
\hline & GTA & 0 & 1 & & $\mathrm{GCA}$ & 4 & 2 & Glu & GAA & 4 & 4 & & GGA & 3 & 6 \\
\hline & GTG & 3 & 5 & & GCG & 1 & 2 & & GAG & 17 & 11 & & GGG & 0 & 1 \\
\hline
\end{tabular}

* Total occurrence of this codon in the deduced amino acid sequence of the inda1 and indc11 genes. 


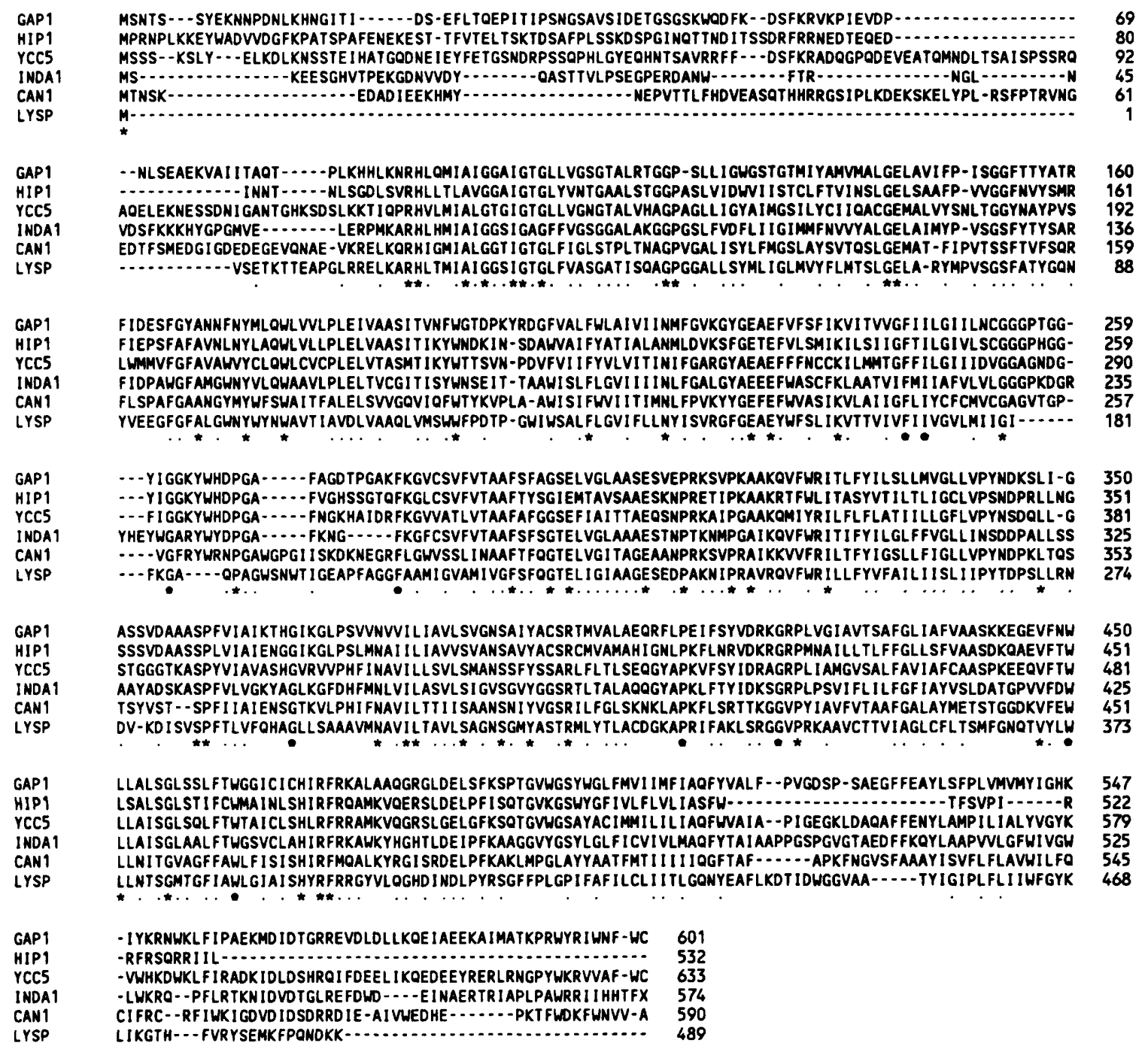

Fig. 4. Comparison of the amino acid sequence deduced for the $T$. harzianum INDA1 protein with amino acid permeases from S. cerevisiae (GAP1, HIP1, YCC5 and CAN1), and E. coli (LYSP). See Results for source of data. Asterisks indicate identical residues, dots indicate similar residues and hyphens indicate gaps inserted into the sequences to maximize alignment.

(Fig. 6) which encodes a protein of 340 amino acid residues with a predicted molecular mass of $37010 \mathrm{Da}$ and a calculated pI value of $8 \cdot 25$. The indc11 nucleotide and amino acid sequences do not display a high degree of homology with any sequence deposited in the databanks. A typical $\mathrm{N}$-terminal sequence resembling signal sequences for excreted proteins was not found (Intelligenetics), suggesting that the INDC11 is not a secreted protein. The DNA sequence surrounding the translation initiation site ATG is CCACAATGGC, similar to the consensus sequence CCACCATGGC (Kozak, 1984). The consensus sequence AATAAA, which is thought to be involved in the $3^{\prime}$-end formation and polyadenylation of the precursor mRNA (see review by Ballance, 1991), was found in the indc11 gene at nucleotide position 1351, 19 nucleotides upstream from the apparent poly(A) addition site. No other significant sequence similarities were identified in computer-assisted searches of the databanks. Codon usage data for the $T$. barzianum indc11 gene are presented in Table 1. The coding region of the indc11 gene of $T$. barzianum contains approximately $55 \mathrm{~mol} \% \mathrm{G}+\mathrm{C}$. Of the 61 codons, 6 are not used at all and 12 are used more than 10 times, coding for about $56 \%$ of the amino acid residues of INDC11. Thus codon bias is apparent, a result in agreement with other genes expressed at high levels (Bennetzen \& Hall, 1982; Ballance, 1991). The bases G and $C$ are generally preferred at the third position of the codons. The codon usage of the T. barzianum indc11 gene resembles that of other Trichoderma genes (Vanhanen, 1991; Goldman et al., 1992a).

To determine whether indc 11 is a member of a gene family, we performed DNA blot hybridizations with genomic DNA prepared from $T$. harzianum (Fig. 3b). After 

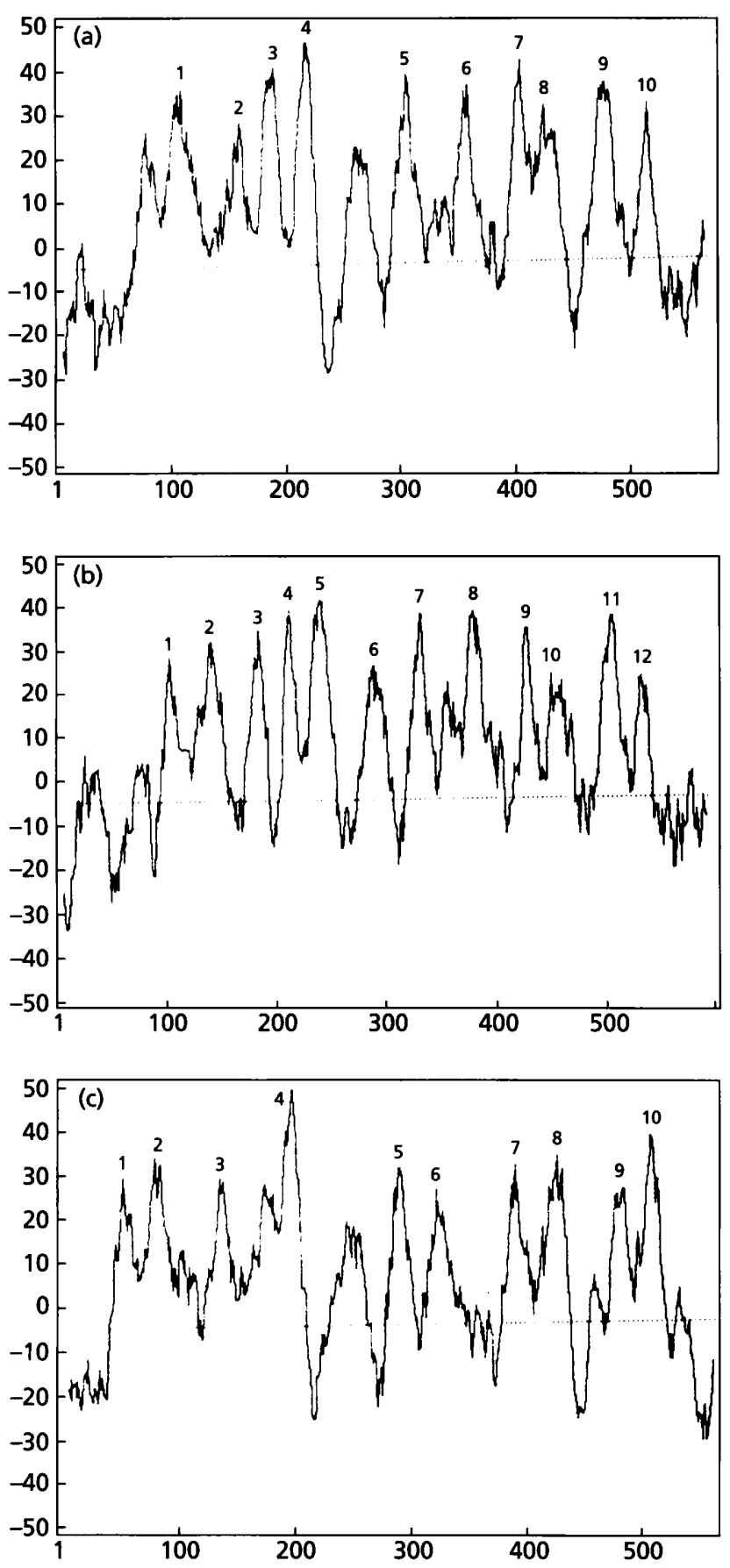

Fig. 5. Hydropathy profiles of the predicted amino acid sequence of the $T$. harzianum INDA1 amino acid transporter (a), $S$. cerevisiae GAP1 general amino acid permease (b), and $A$. nidulans PRNB proline transport protein (c). The profiles of the amino acid transporters are plotted according to Kyte \& Doolittle (1982) from the $\mathrm{N}$-terminus to the C-terminus by averaging hydropathy values over a window of 15 residues.

digestion of the genomic DNA with appropriate restriction enzymes, few fragments that could be identified in the restriction map of the clone hybridized to the INDC11 cDNA, suggesting that indc11 is a single-copy gene.

\section{DISCUSSION}

We have described the isolation and characterization of two cDNA clones that correspond to genes encoding novel putative mycoparasitism-related proteins of $T$. barzianum. These two clones were obtained by differential screening of an induced library and correspond to genes that are expressed during growth on $R$. solani cell walls. One of them corresponds to a gene, inda1, that encodes a putative amino acid permease whereas the other corresponds to a gene, indc11, which is expressed at high levels during mycoparasitism. The indc11 gene encodes a novel polypeptide that does not show any similarity with other proteins deposited in the databanks.

Although the inda 1 gene encodes a presumptive amino acid transporter that shows high similarity to a general amino acid permease of $S$. cerevisiae (see Results), the specificity of the permease activity of INDA1 remains to be elucidated. The hydropathy profile of the INDA1 transport protein is similar to many different permeases (see Results). There is no classical cleavage leader sequence in the INDA1 amino acid permease. All fungal and many bacterial and mammalian transporters lack an N-terminal hydrophobic signal peptide. Blobel (1980) suggested that one or more of the hydrophobic segments of these proteins might function as an 'internal signal peptide'. Further investigation is required to determine the actual role of INDA1 in mycoparasitic interactions, and how its regulation can be affected by a diversity of environmental factors.

It has been proposed that the mycoparasitic activity of Trichoderma proceeds in three major steps (Chet, 1987). Initially, the mycoparasite hyphae grow towards the host hyphae (Chet et al., 1981). Then the parasite attaches to the target hyphae, presumably using a host lectin (Elad et al., 1983a, b; Barak et al., 1985), and appressoria-like structures coil around the attacked cells (Chet et al., 1981; Elad et al., 1983b). Concurrently, degradation of $1,3-\beta$-glucans and chitin from the host cell wall is observed (Elad et al., 1983b). Finally, the mycoparasite penetrates and/or lyses the host hyphae (Chet et al., 1981), releasing the cellular contents and providing nutrients to sustain its growth. Both mechanical pressure and cell-wall-degradation by hydrolytic enzymes are probably involved in the process of penetration. Extracellular enzymes that hydrolyse the main chemical constituents of the fungal cell wall, i.e. chitin, glucans and proteins, were detected when $T$. barzianum was grown on R. solani mycelia or cell walls as sole carbon source (Ridout et al., 1988; Geremia et al., 1991). The enzymes appeared sequentially: first an alkaline proteinase was produced followed by glucanases and chitinases (Geremia et al., 1993; G. H. Goldman \& D. Jacobs, unpublished results). We have recently purified the alkaline proteinase specifically induced by R. solani cell walls and chitin (Geremia et al., 1991) and cloned the corresponding gene (prb1; Geremia et al., 1993). We suggested that PRB1 was involved in the degradation of the phytopathogen cell walls, membranes and possibly proteins released after the lysis of the host, which could then be used as nutrients by the mycoparasite. Thus, the 


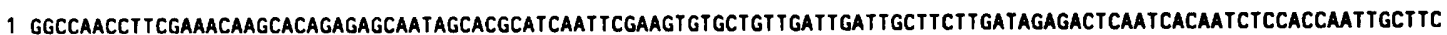
112 GAGGATCTCTCCAACAAGGCCACTACAGATCGGATCCTGCTICAACACCATCACC ACA ATG GCC ATC CCC AAC CGC AAA GTC GTC ATC ACC GCC TAC \begin{tabular}{lllllllllll}
$M$ & $A$ & $P$ & $N$ & $R$ & $V$ & $V$ & $I$ & $T$ & $A$ & $Y$ \\
\hline
\end{tabular} 209 GGC CCC CCC TCC ACC GCC CTC CAG TTC GTC ACC GAG GAT CTG CCC CCG CCCG CCC AAG GAC CAC GTC CAG GTC AAG ATC CTC TAC $V_{P}$

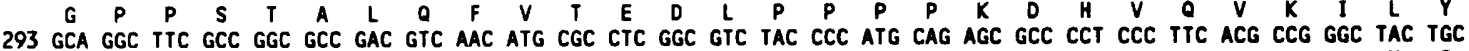

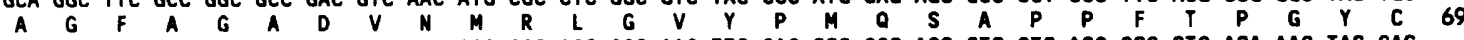
377 TTC GCC GGC CGC GTC TCC GTC AAC GGG CCC GGC AGC GGC AAG TTC GAG CCC GGC ACC CTC GTC ACG GCG CTG ACA AAG TAC GAC

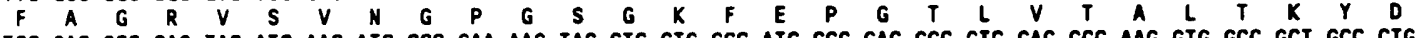
461 TCC GAC GCC GAG TAC ATC AAC ATC CCC GAA AAG TAC CTC CTG GCC ATC CCC GAC GGC GTC GAC CCC AAG GTG GCC GCT GCC CTG

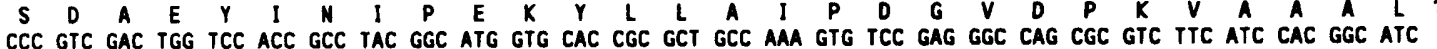
545 CCC GTC GAC TGG TCC ACC GCC TAC GGC ATG GTG CAC CGC GCT GCC AAA GTG TCC GAG GGC CAG CGC GTC TTC ATC CAC GGC ATC 153 629 AGC GGA GCA GIT GGC CAG GCC GTC ATG TAT CTC TCG CTC CTC CAG GGC GCC ACC GTC TAC GGC ACG GCC TCT GAG AGG MAC CAC

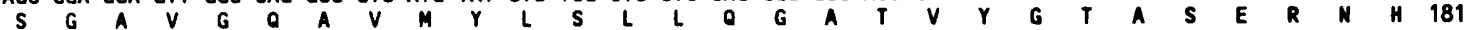
713 GCC GCC CTC AAG GAA GCA GGC GCC CAT CCG TAC CTC TAC ACC AAC AAG GAC TGG ATC GCG GCC ATG AAG GAC CTC GGC GGC GTG $A$ A $L$ K $E$ E A G A H P Y 797 CAC GCT GTG IIT GAC GCC CTG GGC ITT GAA AGC TIC GAC GAG TCC TAC TCC ATC TTG ACT CCC AAG GAG AGA AGC GTA GTC GTC $\begin{array}{lllllllllllllllllllllllllllll}H & A & V & F & D & A & L & G & F & E & S & F & D & E & S & Y & S & I & L & T & P & K & E & R & S & V & V & V & 237\end{array}$ 889 GCC TAC GGA AAC AAC CTC AGC AAT CTC ACT GGT GCG AAG CGG CGC AGC CCT TGG ATC CCC ATG GCC AAG CTG CTA TIC AMG MAT

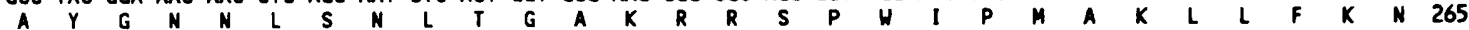
964 CTC TAT TIC TGG TCC AAC AAG GGA GCT ATA TIC IAC IIC ATC ACG CGC GAC CAA AAG ACG TIT GAG CCT GAA CTG CAG CTG CTG $\begin{array}{lllllllllllllllllllllllllllll}L & Y & F & W & S & N & K & G & A & I & F & Y & F & I & T & R & D & Q & K & T & F & E & P & E & L & 0 & L & L & 293\end{array}$ 1049 CTC AAC ATG ACC AGG GAT GGA ATC ATT ACC CCT CCG ATC AAG GCC GTC TGG GAG TIT GAC GAT ATC AAA GAG GCC CAT GAG GCT

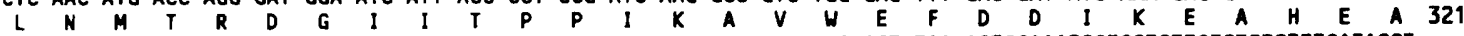
1133 TGG TGC AAG GGC TCA GGA ATG GGA TCG CCA GIT ATC CGC ATC GCC CGC GAC GCT TAA AGTGGAAATCGTGCTCTTGTCTCTCTTTGATACCT $H C K$ G $S$ G M G S P V I R I A R D A. 1225 CGTITAATAGTGTCTTGATITGGTTAAAGATIGTTGICGGATCTGCAGCGGTITICTGTTAITGTCTCCICCCCAATITAATTCCCAATTATITAGTICAGCAACTTGAAA 1336 CATTCACTAATIAATAATAAAATCCATGTACTTTGTCTGCAAAAAAAAAAAAAAAAAAAAAAAAAAAA

Fig. 6. Nucleotide sequence and predicted amino acid sequence of the $T$. harzianum indc11 gene $(1.2 \mathrm{~kb} S f i l-N o t l$ fragment).

mycoparasite could utilize amino acids derived from the enzymic hydrolysis of these proteins as carbon and/or nitrogen sources. Consequently, the uptake of these amino acids will be of importance for the nutrition of the mycoparasite. The coordinated transcription of the prb1 and inda1 genes fits this model, but formal proof of this hypothesis must await additional studies.

The use of this methodology for identifying and characterizing mycoparasitism-related genes should provide more biochemical information about mycoparasitism and provide specific genetic markers to follow the biological interaction. Further steps in this direction would be specific knock-out of the inda 1 and indc11 genes in order to prove their role in mycoparasitism. Additionally, investigations will be carried out into the development of better biocontrol strains of Trichoderma spp. In this regard, the fact that inda1 and indc11 genes are expressed during growth on $R$. solani cell walls suggests that their promoters could be useful for many types of genetic engineering. The fusion of genes coding for products that are inhibitory to plant pests could, under the control of these promoters, have great potential for producing transgenic Trichoderma strains with enhanced biocontrol activity. Enzymes that degrade fungal cell walls, especially chitinases or glucanases, may be attractive candidates for such products.

\section{ACKNOWLEDGEMENTS}

The authors wish to thank Drs Debra Winger and Prem Das for critical reading of the manuscript; Jan Gielen and Luc Van Wiemeersch for databank searches and alignment of various nucleotide sequences; Wilson Ardiles and Hilde Demets for sequencing; Martine De Cock for help with the manuscript; and Karel Spruyt and Vera Vermaercke for drawings and photographs. G.H.G. and V.V. are indebted to CAPES-Brazil and the Commission of the European Communities, respectively, for fellowships.

\section{REFERENCES}

Ahmad, M. \& Bussey, H. (1986). Yeast arginine permease: nucleotide sequence of the CAN1 gene. Curr Genet 10, 587-592.

Avent, A. G., Hanson, J. R. \& Truneh, A. (1992). The biosynthesis of harzianolide by Trichoderma barzianum. Phytochemistry 31 , 791-793.

Ballance, J. D. (1991). Transformation systems for filamentous fungi and an overview of fungal gene structure. In Molecular Industrial Mycology. Systems and Applications for Filamentous Fungi, pp. 1-29. Edited by S. A. Leon \& R. M. Berka. New York: Marcel Dekker.

Barak, R., Elad, Y., Mirelman, D. \& Chet, I. (1985). Lectins: a possible basis for specific recognition in the interaction of Trichoderma and Sclerotium rolfsii. Pbytopatbology 75, 458-462.

Bennetzen, J. L. \& Hall, B. D. (1982). Codon selection in yeast. J Biol Chem 257, 3026-3031.

Blobel, G. (1980). Intracellular protein topogenesis. Proc Natl Acad Sci US A 77, 1496-1500.

Chet, I. (1987). Trichoderma - application, mode of action, and potential as a biocontrol agent of soilborne plant pathogenic fungi. In Pests - Biological Control, pp. 137-160. Edited by I. Chet. New York: John Wiley.

Chet, I. (1990). Biological control of soil-borne plant pathogens with fungal antagonists in combination with soil treatments. In Biological Control of Soil-Borne Plant Pathogens (Series in Ecological and Applied Microbiology), pp. 15-25. Edited by D. Hornby. Wallingford: CAB International.

Chet, l., Harman, G. E. \& Baker, R. (1981). Trichoderma hamatum; its hyphal interactions with Rhizoctonia solani and Pythium spp. Microb Ecol 7, 29-38.

Claydon, N., Hanson, J. R., Truneh, A. \& Avent, A. G. (1991). Harzianolide, a butenolide metabolite from cultures of Trichoderma harzianum. Phytochemistry 30, 3802-3803.

De La Cruz, J., Hidalgo-Gallego, A., Lora, J. M., Benitez, T., PintorToro, J. A. \& Llobell, A. (1992). Isolation and characterization of three chitinases from Trichoderma barzianum. Eur J Biochem 206, 859-867. 
Dennis, C. \& Webster, J. (1971a). Antagonistic properties of species-groups of Trichoderma. I. Production of non-volatile antibiotics. Trans Br Mycol Soc 57, 25-39.

Dennis, C. \& Webster, J. (1971b). Antagonistic properties of species-groups of Trichoderma. II. Production of volatile antibiotics. Trans Br Mycol Soc 57, 41-48.

Di Pietro, A., Lorito, M., Hayes, C. K., Broadway, R. M. \& Harman, G. E. (1993). Endochitinase from Gliocladium virens: isolation, characterization, and synergistic antifungal activity in combination with gliotoxin. Pbytopathology 83, 308-313.

Elad, Y., Chet, I. \& Henis, Y. (1982). Degradation of plant pathogenic fungi by Trichoderma harzianum. Can J Microbiol 28, 719-725.

Elad, Y., Barak, R. \& Chet, I. (1983a). Possible role of lectins in mycoparasitism. J Bacteriol 154, 1431-1435.

Elad, Y., Chet, I., Boyle, P. \& Henis, Y. (1983b). Parasitism of Trichoderma spp. on Rhizoctonia solani and Sclerotium rolfsii-scanning electron microscopy and fluorescence microscopy. Phytopathology 73, 85-88.

Garber, R. C. \& Yoder, O. C. (1983). Isolation of DNA from filamentous fungi and separation into nuclear, mitochondrial, ribosomal, and plasmid components. Anal Biocbem 135, 416-422.

Gasser, C. S., Budelier, K. A., Smith, A. G., Shah, D. M. \& Fraley, R. T. (1989). Isolation of tissue specific cDNAs from tomato pistils. Plant Cell 1, 15-24.

Geremia, R., Jacobs, D., Goldman, G. H., Van Montagu, M. \& Herrera-Estrella, A. (1991). Induction and secretion of hydrolytic enzymes by the biocontrol agent Trichoderma barzianum. In Biotic Interactions and Soil-borne Diseases (Developments in Agricultural and Managed-Forest Ecology Series vol. 23), pp. 181-186. Edited by A. B. R. Beemster, G. J. Bollen, M. Gerlagh, M. A. Ruissen, B. Schippers \& A. Tempel. Amsterdam: Elsevier.

Geremia, R., Goldman, G. H., Jacobs, D., Ardiles, W., Vila, S. B., Van Montagu, M. \& Herrera-Estrella, A. (1993). Molecular characterization of the proteinase-encoding gene, $p r b 1$, related to mycoparasitism by Trichoderma barzianum. Mol Microbiol 8, 603-613.

Goldman, G. H., Geremia, R. A., Caplan, A. B., Vila, S. B., Villarroel, R., Van Montagu, M. \& Herrera-Estrella, A. (1992a). Molecular characterization and regulation of the phosphoglycerate kinase gene from Trichoderma viride. Mol Microbiol 6, 1231-1242.

Goldman, G. H., Demolder, J., Dewaele, S., Herrera-Estrella, A., Geremia, R. A., Van Montagu, M. \& Contreras, R. (1992b). Molecular cloning of the imidazoleglycerolphosphate dehydratase gene of Trichoderma harzianum by genetic complementation in Saccharomyces cerevisiae using a direct expression vector. Mol \& Gen Genet 234, 481-488.

Goldman, G. H., Temmerman, W., Jacobs, D., Contreras, R., Van Montagu, M. \& Herrera-Estrella, A. (1993). A nucleotide substitution in one of the $\beta$-tubulin genes of Trichoderma viride confers resistance to the antimitotic drug methyl benzimidazole-2-ylcarbamate. Mol \& Gen Genet 240, 73-80.

Goldman, M. H. de S., Pezzotti, M., Seurinck, J. \& Mariani, C (1992). Developmental expression of tobacco pistil-specific genes encoding novel extensin-like proteins. Plant Cell 4, 1041-1051.

Gott, P. \& Boos, W. (1988). The transmembrane topology of the $s n$ glycerol-3-phosphate permease of Escherichia coli analysed by pho $A$ and lac $Z$ protein fusions. Mol Microbiol 2, 655-663.

Graeme-Cook, K. A. \& Faull, J. L. (1991). Effect of ultravioletinduced mutants of Trichoderma barzianum with altered antibiotic production on selected pathogens in vitro. Can J Microbiol 37, 659-664.

Harman, G. E., Hayes, C. K., Lorito, M., Broadway, R. M., Di Pietro, A., Peterbauer, C. \& Tronsmo, A. (1993). Chitinolytic enzymes of Trichoderma barzianum: purification of chitobiosidase and endochitinase. Phytopathology 83, 313-318.

Hayes, C. K., Klemsdal, S., Lorito, M., Di Pietro, A., Peterbauer, C., Nakas, J. P., Tronsmo, A. \& Harman, G. E. (1994). Isolation and sequence of an endochitinase-encoding gene from a cDNA library of Trichoderma barzianum. Gene 138, 143-148.

Hoffmann, w. (1985). Molecular characterization of the $C A N 1$ locus in Saccharomyces cerevisiae. A transmembrane protein without $\mathrm{N}$-terminal hydrophobic signal sequence. J Biol Chem 260, 1183111837.

Jones, J. D. G., Dunsmuir, P. \& Bedbrook, J. (1985). High level expression of introduced chimaeric genes in regenerated transformed plants. EMBO J 4, 2411-2418.

Kozak, M. (1984). Selection of initiation sites by eucaryotic ribosomes: effect of inserting AUG triplets upstream from the coding sequence for preproinsulin. Nucleic Acids Res 12, 3873-3893.

Kyte, J. \& Doolittle, R. F. (1982). A simple method for displaying the hydropathic character of a protein. J Mol Biol 157, 105-132.

Lorito, M., Harman, G. E., Hayes, C. K., Broadway, R. M., Tronsmo, A., Woo, S. L. \& Di Pietro, A. (1993). Chitinolytic enzymes produced by Trichoderma harzianum: antifungal activity of purified endochitinase and chitobiosidase. Phytopathology 83, 302307.

Manocha, M. S. (1991). Physiology and biochemistry of biotrophic mycoparasitism. In Soil and Plants (Handbook of Applied Mycology vol. 1), pp. 273-300. Edited by D. K. Arora, B. Rai, G. K. Mukerji \& G. R. Knudsen. New York: Marcel Dekker.

Ridout, C. J., Coley-Smith, J. R. \& Lynch, J. M. (1986). Enzyme activity and electrophoretic profile of extracellular protein induced in Trichoderma spp. by cell walls of Rbizoctonia solani. J Gen Microbiol 132, 2345-2352.

Ridout, C. J., Coley-Smith, J. R. \& Lynch, J. M. (1988). Fractionation of extracellular enzymes from a mycoparasitic strain of Trichoderma barzianum. Enzyme Microb Technol 10, 180-187.

Sambrook, J., Fritsch, E. F. \& Maniatis, T. (1989). Molecular Cloning: a Laboratory Manual, 2nd edn. Cold Spring Harbor, NY: Cold Spring Harbor Laboratory.

Sanger, F., Nicklen, S. \& Coulson, A. R. (1977). DNA sequencing with chain-terminating inhibitors. Proc Natl Acad Sci US A $\mathbf{7 4}$, 5463-5467.

Sophianopoulou, V. \& Scazzocchio, C. (1989). The proline transport protein of Aspergillus nidulans is very similar to amino acid transporters of Saccbaromyces cerevisiae. Mol Microbiol 3, 705-714.

Steffes, C., Ellis, J., Wu, J. \& Rosen, B. P. (1992). The $l y s P$ gene encodes the lysine-specific permease. $J$ Bacteriol 174, 3242-3249.

Tanaka, J.-i. \& Fink, G. R. (1985). The histidine permease gene (HIP1) of Saccharomyces cerevisiae. Gene 38, 205-214.

Ulhoa, C. J. \& Peberdy, J. F. (1991). Regulation of chitinase synthesis in Trichoderma barzianum. J Gen Microbiol 137, 2163-2169.

Vanhanen, S. (1991). Isolation and characterization of genes involved in basic metabolism of the filamentous fungus Trichoderma reesei. Academic dissertation, University of Helsinki (Technical Research Centre of Finland Publications no. 75).

Received 22 September 1994; accepted 5 December 1994. 